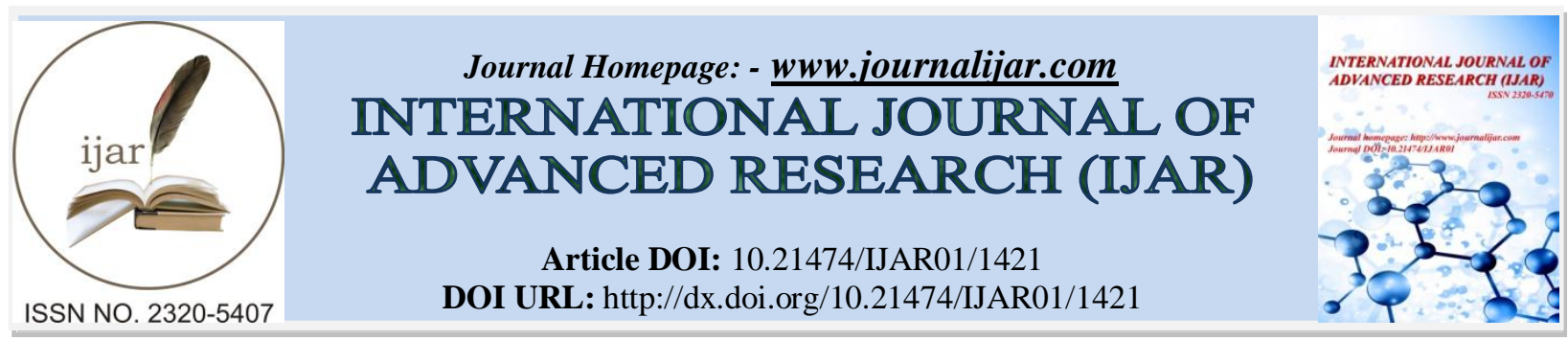

RESEARCH ARTICLE

\title{
INVESTMENT AWARENESS AMONG INDIAN WORKING WOMEN WITH REFERENCE TO JALNA DISTRICT.
}

1. Research Scholar, D.M.M., Jalna.

Miss. Manju Rameshchand Mutha ${ }^{1}$ and Dr. S. O. Dargad ${ }^{2}$.

2. Associate Professor, Smt. DMM, Jalna.

\section{Manuscript Info}

Manuscript History

Received: 12 June 2016

Final Accepted: 19 July 2016

Published: August 2016

Key words:-

Financial Investment, Financial planning, Investment Decision.

\section{Abstract}

From ancient times, women have been managing homes. Hence they are called 'Home makers'. But since the last 10 to 15 years, this situation has been changing. These days, in all sorts of fields, women are working efficiently and enthusiastically along with men or if it is said that women work more efficiently than their male colleagues, it wouldn't be an exaggeration. As the name suggests, the present research has been done to know the investment awareness among Indian working women with reference to Jalna District. Now - a days, women want to be financially independent $\&$ secure their future with enough funds. This research is based on the study of investment behavior \& patterns followed by working women in various sectors in Jalna District.

Copy Right, IJAR, 2016,. All rights reserved.

\section{Introduction:-}

The word "Awareness" refers to a consciousness of the existence of a particular truth, event or thing. Hence, awareness is a course of action by which, one known's the existence of a new thing. This process of knowledge makes a man to have an idea about a thing which he has not known earlier. How-ever, he may not have a thorough knowledge of that thing. Acquiring the knowledge of the latest developments in a particular field also amounts to awareness and hence awareness is a continuous process. Lokhande M.A. (2015) concluded that there was no significant difference in awareness levels of rural male and female investors and their educational qualifications. The investment preference order of the respondents indicated that they wished to park their investments in 'safe' options only. Bank deposits, gold and jewelry, real estate were popular investment avenues for a majority of the investors.

In the ancient times, women were not allowed to even get education. Their role was purely to look after home. Their world was limited to their families. But then, the peoples slowly started recognizing the importance of education for women and today, we find many highly educated women. They are progressing in real sense because in almost all sectors we find women working successfully. And of course, while doing so, they haven't forgotten their job of homemaker. On both the fronts i.e. home \& job, they are doing just fine. They know how to manage work life balance. Now-a-days, we find more and more women who are financially independent. No doubt, today's women are more successful. They are getting paid handsome salaries. But what about their investment behavior? Are they financially aware enough to make their own investment? If yes, then what are their investment patterns? What are their perceptions towards saving and investment, what is their risk bearing capacity? The answers to these questions 
are necessary for getting the picture of the role of Indian working women while taking the investment decisions. Financial investment is the purchase of a financial security such as stock, bond or mortgage. As a woman \& an investor, shaping of financial future is as the many other roles they play in life. Lokhande, M.A. (2004) Electronic media, efficiency transportation system, increasing income levels and strategic marketing policies are the major contributing factors to enhance to the scope of rural Marketing. Rural consumer is changing his consumption habits to suit himself to changing environment Women today, have more earning potential \& more influence over financial decisions than ever before. Women represent almost half of the workforce \& many businesses are owned or managed by women. Many women influence or control the majority of all consumer decisions. As a result, it becomes important for women to focus on finances now more than ever. Throughout their lives, as a woman, they face different financial challenges than their male counterparts. If women are going to take control of their financial future, it's important that they recognize those differences \& empower themselves.

\section{Objective of the study:-}

1. To know the importance of Investment for women.

2. To study the role of working women in making investment decisions.

3. To study the investment avenues that the Indian working women usually prefer.

4. To study the investment habits of the working women in Jalna District.

\section{Research Methodology:-}

The study is based on the data collected from the individual investors in Jalna District. Working women in different industry sectors were interviewed for this purpose. Working professional from Banks, Private Sector, government, Teacher. Convenient sampling technique has been used in order to collect data from 100 female respondents which were collected for a period of 9 months i.e. January 2014- September 2014 through structured questionnaire. For the purpose of the study all the Talukas from Jalna district i.e. Bhokardan, Jafrabad, Badnapur, Jalna, Ambad, Ghansavangi, Partur, Mantha is selected. In order to analyze the data, weighted score ranking method is used. Simple average percentage and technique is also used for finding the results. Secondary data is available through journals, periodicals and publications.

\section{Importance of Investment for Women:-}

As a woman, the life expectancy is high as compared to males: hence it is very much essential to have enough investment to maintain the lifestyle throughout their lives. Earning money is only half the equation for achieving financial independence. Effectively putting your money to work for you is equally important. In addition, circumstances are frequently different for women, and whatever choices you make will be better as a result of greater knowledge of the underlying issues \& your options. It is always observed that women are no risk taker while doing investment decisions. If they educate themselves well about investment avenues \& the returns which can be availed from them, they can take important and bold decisions for making investment.

\section{Financial Planning Process:-}

Financial planning is an ongoing process to help you make sensible decisions about money that can help you achieve your goals in life. A sound financial plan must include the following steps:

- Establishing the goals in life: short, medium \& long term

- Working out what assets \& liabilities we have

- Evaluating our current financial position

- Developing our plan

- Implementing the plan

- Monitoring \& reviewing the plan at least yearly \& making adjustments when needed.

Analysis of working women in Jalna district:-

Information Regarding Investment Avenues: - Indian working women invest in various types of investment avenues. It is classified in eight categories in table no.-1.

It appears from that majority of the respondents i.e.98 percent were made investments in Gold. 92 percent sample investors recognized the provident fund. It is followed by fixed deposit product which was known to 91 percent of sample. 67 percent respondents were invested in post office saving scheme and 59 percent respondents were invested in National saving certificate and National saving scheme. It reveals that 48 percent respondents were 
invested in Insurance product. 11 percent \& 10 percent respondents were invested in Kisan vikas patra, Indra vikas patra and Share, Debenture, Bonds respectively.

Table 1:- Information Regarding Investment Avenues

\begin{tabular}{|l|c|c|c|c|c|c|}
\hline Avenues & Bank & Private sector & Govt. & Teacher & Total & Percentage \\
\hline Total Respondent & 31 & 17 & 21 & 31 & 100 & \\
\hline Gold & 31 & 15 & 21 & 31 & 98 & $98 \%$ \\
\hline Provident Fund & 31 & 09 & 21 & 31 & 92 & $92 \%$ \\
\hline Fixed deposit & 31 & 13 & 18 & 29 & 91 & $91 \%$ \\
\hline Post office saving & 24 & 08 & 14 & 21 & 67 & $67 \%$ \\
\hline NSC,NSS & 19 & 09 & 12 & 19 & 59 & $59 \%$ \\
\hline Insurance & 17 & 12 & 08 & 11 & 48 & $48 \%$ \\
\hline KVP,IVP & 01 & 02 & 04 & 04 & 11 & $11 \%$ \\
\hline Share, Debenture and Bonds & 03 & 04 & 02 & 01 & 10 & $10 \%$ \\
\hline Total & 158 & 72 & 100 & 147 & 409 & \\
\hline
\end{tabular}

Source: Primary Data

The table No.1 shows that,

Purpose of Investment:- Investing purpose of working women classified into four categories- Future planning, Tax saving, High Return, safety.

Table 2:- Purpose of Investment.

\begin{tabular}{|l|c|c|c|c|c|c|}
\hline \multicolumn{1}{|c|}{ Purpose } & Bank & Private sector & Govt. & Teacher & Total & Percentage \\
\hline Tax saving & 31 & 14 & 21 & 31 & 100 & $97 \%$ \\
\hline Future planning & 31 & 16 & 18 & 29 & 94 & $94 \%$ \\
\hline Safety & 31 & 15 & 19 & 28 & 93 & $93 \%$ \\
\hline High Return & 08 & 12 & 06 & 05 & 31 & $31 \%$ \\
\hline Total & 101 & 60 & 64 & 93 & 318 & \\
\hline
\end{tabular}

Source: Primary Data

The table no. 2 shows that 97 percent respondents doing investment for Tax saving purpose. The data reveals that 94 percent respondents doing investment for future planning. 93 percent respondents were doing investment safety purpose and 31 percent respondents were invested for High return.

Investment Decision:- Working women investors take investment decision Self or with help of friends, Family member, Experts, Auditors and Advertisement.

Table 3:- Investment Decision.

\begin{tabular}{|l|c|c|c|c|c|c|}
\hline $\begin{array}{c}\text { Reference } \\
\text { Group }\end{array}$ & Bank & Private sector & Government & Teacher & Total & $(\%)$ \\
\hline Auditors & 28 & 08 & 20 & 29 & 85 & $85 \%$ \\
\hline Self & 22 & 14 & 07 & 27 & 70 & $70 \%$ \\
\hline Friends & 18 & 09 & 08 & 10 & 45 & $45 \%$ \\
\hline Experts & 11 & 07 & 04 & 06 & 28 & $28 \%$ \\
\hline Family Member & 04 & 03 & 02 & 04 & 13 & $13 \%$ \\
\hline Advertisement & 04 & 02 & 03 & 04 & 13 & $13 \%$ \\
\hline Total & 87 & 43 & 44 & 80 & 254 & \\
\hline
\end{tabular}

Source: Primary Data

The table no. 3 shows that,

The data reveals that 85 percent respondents were taking decision with the help of auditors. It is followed that 70 percent respondents doing investment Self and 45 percent respondents followed Friends opinion. It appears that 28 percent respondents were doing investment from expert suggestion. Just 13 percent respondents were taking decision with the help of family members and advertisement. 


\section{Conclusion:-}

Jalna District is on the path of growth in real sense. Not only it is known for the best education, it has now become the 'Employment Hub' as well. Because of high level education, today's women are getting the best job offers with high take packages. It has become the present day need for working women in India to increase their wealth. As most of the women are low in financial literacy, it becomes hardly possible for them to manage their portfolios on their own. Also the risk bearing capacity of working women in India is low. This is due to lack of sound financial knowledge.

\section{References:-}

1. Brian M. Lucey and Michael Dowling (2005), The Role of Feeling in Investor Decision making, Journal of Economic Surveys, Vol.19, No.2, Blackwell Publishing Ltd.

2. De Long, J. Brandford and Anderi Shleifer, "The Stock Market Bubble of 1929:Evidence from Closed- End Mutual Funds,” Journal of Economic History, 51(3):375-700,1991.

3. Lokhande, M.A. (2015) A Study of Investment Awareness and Patterns of Savings and Investments by Rural Investors, Indian Journal of Finance, Volume 9, Issue 7, July 2015, pp, 22-31.

4. Desigan et al. (2006), "Women Investor's perception towards Investment: An empirical Study", Indian Journal of Marketing.[Online] Available: http://www.google.com. (Accessed on 22 ${ }^{\text {nd }}$ May 2010).

5. Donald E Fischer, Ronald J Jordan., (1995), Security Analysis and Portfolio Management, Prentice Hall.

6. Lokhande, M.A. (2004) Rural Marketing - A Study Of Consumer Behaviour, Indian Journal of Marketing, Vol. xxxiv, Dec., 2004.

7. 'Indian streams Research Journal' International Recognized Multidisciplinary (ISSN NO.2230-7850).

8. Brennam, M.J. (1995), The Individual investors, The Journal of Financial Research, Vol.XVIII, No.1, pp59-74. 